Zeszyty Naukowe Szkoły Głównej Gospodarstwa Wiejskiego w Warszawie Problemy Rolnictwa Światowego tom 17 (XXXII), zeszyt 2, 2017: 18-28

DOI: $10.22630 /$ PRS.2017.17.2.23

Jerzy Bieńkowski ${ }^{1}$, Małgorzata Holka, Janusz Jankowiak

Instytut Środowiska Rolniczego i Leśnego Polskiej Akademii Nauk w Poznaniu

\title{
Ocena emisji GHG za pomocą śladu węglowego w intensywnej produkcji rolniczej, na przykładzie rzepaku ozimego
}

\section{Assessing the Greenhouse Gas Emissions by Carbon Footprint in Intensive Agricultural Production Based on the Examples of Winter Oilseed Rape}

\begin{abstract}
Synopsis. Aktualnie ważnym wyzwaniem dla sektora rolniczego jest redukcja emisji gazów cieplarnianych $(\mathrm{GHG})$ w celu złagodzenia skutków zmian klimatycznych. Istnieje potrzeba dokładnej identyfikacji źródeł emisji oraz upowszechnienia praktyk rolniczych, które przyczyniałyby się do zmniejszenia emisji we wszystkich ogniwach produkcji roślinnej. Do przeprowadzenia obiektywnych porównań i wyboru najlepszych rozwiązań technologicznych według kryterium emisyjności potrzebna jest szczegółowa ocena ilościowa emisji GHG. W opracowaniu przedstawiono ocenę emisji GHG w produkcji roślinnej za pomocą śladu węglowego (CF). Udział operacji technologicznych w powstawaniu CF scharakteryzowano na przykładzie rzepaku ozimego. Wyniki badań wskazują, że największe znaczenie w kształtowaniu CF ma proces nawożenia mineralnego. Wpływ pozostałych procesów na CF jest wielokrotnie mniejszy. Miejscem głównych emisji GHG w nawożeniu mineralnym rzepaku są emisje bezpośrednie i pośrednie GHG z pól. Po emisjach GHG z pól, produkcja nawozów stanowi drugie źródło emisji z nawożenia. Zmiany praktyk rolniczych polegających na zwiększeniu efektywności nawożenia azotowego oraz stosowaniu nawozów o niskich współczynnikach emisji stwarzają obecnie możliwość redukcji emisji GHG i przez to, tym samym mogą przyczynić się do zmniejszenia CF produktów roślinnych.
\end{abstract}

Słowa kluczowe: ślad węglowy, gazy cieplarniane, produkcja roślinna, nawożenie azotowe, praktyki rolnicze, rzepak ozimy

\begin{abstract}
Currently, a major challenge for the agriculture sector is the reduction of greenhouse gas (GHG) emissions in order to mitigate the effects of climate change. There is a need to accurately identify the sources of emissions and to promote agricultural practices that would contribute to the reduction of emissions in all chains of crop production. To carry out objective comparisons and choose the best technological solutions according to an emissivity criterion there is a need for the detail quantitative assessment of GHG emissions. The study shows an assessment of GHG emissions in crop production using the carbon footprint (CF). The share of technological operations in $\mathrm{CF}$ formation was characterized based on the example of winter oilseed rape. The results indicate that the process of fertilization is of the greatest importance in the CF development. The impact of other remaining processes on the $\mathrm{CF}$ is several times smaller. The main hot-spots in GHG emissions due to mineral fertilization are associated with direct and indirect GHG emissions from the fields. Emissions from the production of fertilizers are the second source of emissions from the fertilization process, following GHG emissions from the fields. Changes in agricultural practices by increasing the efficiency of nitrogen fertilization and the use of fertilizers with low emission factors make it possible to reduce GHG emissions at present, and thereby contribute to the CF reduction of crop products.
\end{abstract}

Key words: carbon footprint, greenhouse gases, crop production, nitrogen fertilization, agricultural practices, winter oilseed rape

\footnotetext{
${ }^{1}$ dr hab., prof. IŚRL PAN, Zakład Systemów Produkcji Rolniczej, Instytut Środowiska Rolniczego i Leśnego PAN, ul. Bukowska 19, 60-809 Poznań, e-mail: bjerzy@onet.pl
} 


\section{Wprowadzenie}

Badania naukowe wskazuja, że obserwowane w ostatnim czasie zmiany klimatyczne $\mathrm{w}$ wielu rejonach świata powodowane są wzrastającą emisją gazów cieplarnianych (GHG) ze źródeł antropogenicznych. Emisje GHG w rolnictwie odnosi się zasadniczo do trzech gazów: podtlenku azotu $\left(\mathrm{N}_{2} \mathrm{O}\right)$, metanu $\left(\mathrm{CH}_{4}\right)$ i dwutlenku węgla $\left(\mathrm{CO}_{2}\right)$, z uwagi na ich duże ilości emitowane $\mathrm{w}$ całym cyklu produkcji rolniczej. W produkcji rolniczej większe znaczenie w ogólnej emisji GHG mają emisje $\mathrm{N}_{2} \mathrm{O}$ i $\mathrm{CH}_{4}$ w porównaniu do emisji $\mathrm{CO}_{2}$ (Bieńkowski i in., 2016). Znaczenie wpływu $\mathrm{N}_{2} \mathrm{O}$ i CH $\mathrm{CH}_{4}$ na tworzenie efektu cieplarnianego wynika z ich wysokiego wskaźnika potencjału globalnego ocieplenia w stosunku do $\mathrm{CO}_{2}$ wynoszącego odpowiednio 298 i 25 (Solomon i in., 2007). Przyjęcie przez kraje UE w 2013 roku planu działania na rzecz redukcji emisji gazowych w sektorach nie objętych europejskim systemem handlu uprawnieniami do emisji wymaga ograniczenia emisji gazów cieplarnianych (GHG) o 30\% do roku 2030 (European Council Conclusions, 2014).

Zaniepokojenie zmianami klimatycznymi wyrażają liczne organizacje ekologiczne i konsumenckie, które oczekują rozwoju i upowszechniania efektywnych sposobów redukcji emisji GHG w działalności produkcyjnej. Skutki zmian klimatycznych odczuwane są także przez rolnictwo. Charakteryzują się one między innymi wzrostem średnich temperatur powietrza, częstszym występowaniem ekstremalnych zjawisk pogodowych, niekorzystnymi zmianami rozkładu czasowego i przestrzennego opadów atmosferycznych, ograniczoną dostępnością wody oraz nasileniem chorób grzybowych i szkodników w uprawach rolnych. W rolnictwie do powstawania emisji GHG przyczyniają się w różnym stopniu produkcja roślinna, zwierzęca, przetwórstwo żywności oraz przechowalnictwo i transport produktów. Rolnictwo w Polsce generowało w 2014 roku około 30,4 mln ton GHG, wyrażonych w ekwiwalencie $\mathrm{CO}_{2}$. Blisko 52,6\% emisji GHG stanowią emisje gazowe z produkcji zwierzęcej (Poland's..., 2016). Pośrednie formy emisji GHG związane są $\mathrm{z}$ produkcją przemysłową nawozów mineralnych, środków ochrony roślin oraz $\mathrm{z}$ produkcją maszyn i urządzeń.

W krajach rozwiniętych tworzone są systemy etykietowania produktów informujące o wielkości emisji $\mathrm{CO}_{2}$ wyrażanej za pomocą tzw. śladu węglowego (CF) produktu. Producenci żywności, znajdując się pod presją polityk środowiskowych oraz kształtowania się ekologicznych kryteriów wyboru żywności przez konsumentów, są skłonni do modyfikacji praktyk rolniczych, które zmniejszałyby oddziaływanie rolnictwa na środowisko. W najbliższym czasie bardzo duże znaczenie dla dalszego rozwoju systemów rolniczych będzie miało opracowanie zintegrowanych strategii i praktyk rolniczych ukierunkowanych na zmniejszenie emisji GHG (Golub i in., 2013). Kontrola emisji GHG w sektorach rolnym i spożywczym powinna być także traktowana jako ważny instrument wspierania zarządzania środowiskowego, mający na celu łagodzenie skutków zmian klimatycznych. W kontekście globalnego wzrostu zapotrzebowania na żywność, wysiłki redukcyjne w zakresie emisji muszą koncentrować się na wszystkich ogniwach łańcucha produkcyjnego żywności (Matthews i in., 2008).

Przyjęcie strategii rozwoju energii odnawialnej przyczynia się do rozwoju produkcji rzepaku w UE. W tej strategii wyznaczono cel przewidujący $10 \%$ udział biopaliw w ogólnym zużyciu benzyny i oleju napędowego w transporcie do roku 2020 (Communication..., 2007). Zobowiązanie to następnie potwierdzono w Dyrektywie 2009/28/WE Parlamentu Europejskiego i Rady (2009). Podjęta decyzja nadaje trwały kierunek rozwojowi produkcji biopaliw, który jest widziany jako ważny filar ochrony 
klimatu. Ograniczenie emisji gazów cieplarnianych (GHG) z biodiesla na bazie oleju rzepakowego (produkcja i jego stosowanie) wynosi $45 \%$, przy przeliczeniu na ekwiwalent $\mathrm{CO}_{2}$ na MJ paliwa (Dyrektywa 2009/28/WE..., 2009). Nowo podejmowane działania inwestycyjne związane z przetwarzaniem olejów roślinnych i ich dystrybucją wpisują się w politykę reindustrializacji UE, wzrostu zatrudnienia i zmniejszenia zależności od importowanych paliw kopalnych. Aktualna produkcja oleju rzepakowego w UE zaspokaja około $65 \%$ zapotrzebowania ogółem na biodiesel. Korzystne warunki klimatyczne oraz odpowiednia jakość gleb w UE dla uprawy rzepaku są dodatkowym bodźcem zachęcającym do rozszerzania powierzchni jego uprawy.

Istnieją rozbieżne opinie na temat aspektów ekologicznych związanych $\mathrm{z}$ rozszerzaniem upraw rzepaku. Po stronie korzyści przedstawia się poprawę siedliska rolniczego. Roślina ta uważana jest za cenny komponent zmianowania różnicujący jego ogniwa i zwiększający różnorodność gatunkową krajobrazu rolniczego, zdominowanego głównie przez zboża i kukurydzę. Przyczynia się ona do wzbogacenia gleby w materię organiczną dzięki pozostawianiu dużej ilości resztek pożniwnych na polu. Strona zagrożeń związana jest $\mathrm{z}$ intensywnością produkcji. Wymaga ona stosowania dużych dawek nawożenia azotowego oraz kompleksowej ochrony chemicznej. Zwiększone oddziaływanie pestycydów na środowisko może z kolei zagrażać utrzymaniu bioróżnorodności środowiska rolniczego.

Wykorzystywanie dużych ilości substancji mineralnych i materiałów przemysłowych intensyfikujących produkcję roślinną powoduje nadmierne emisje reaktywnych związków chemicznych do środowiska i ich duży zasięg przestrzenny. Emisje GHG są istotną częścią środowiskowych skutków produkcji rzepaku określonych za pomocą CF. Ze względu na upowszechnienie uprawy tej rośliny w Polsce ważna jest ocena ilościowa emisji GHG oraz identyfikacja źródeł emisji w intensywnym systemie uprawy rzepaku ozimego.

\section{Materiał i metody}

W badaniach prowadzonych przez Instytut Środowiska Rolniczego i Leśnego PAN oszacowano wielkości CF rzepaku ozimego uprawianego w intensywnym systemie uprawowym $\mathrm{w}$ warunkach wielkoobszarowego gospodarstwa rolnego. Dane do analiz pochodziły $\mathrm{z}$ przedsiębiorstwa rolnego położonego $\mathrm{w}$ południowo-zachodniej części województwa Wielkopolskiego. Badania prowadzono w okresie lat 2011-2014.

Ślad węglowy jest pojęciem używanym w ocenie emisji GHG oraz w publicznej dyskusji nad działaniami potrzebnymi dla zmniejszania zagrożeń związanych ze zmianami klimatycznymi. W ogólnym znaczeniu oznacza on emisje gazowe związków, które przyczyniają się do powstawania efektu cieplarnianego w całym cyklu produkcji i spożycia produktów. CF wyraża się w formie sumy iloczynów efektu cieplarnianego dla substancji i wielkości emisji „i-tej” substancji. Obejmuje on zarówno emisje bezpośrednie, jak i pośrednie, które powstają w całym cyklu życia produktu. Przedstawia się go w postaci kwantyfikowalnych ilościowo wskaźników: a) jako ogólną emisję GHG w kg ekwiwalentu $\mathrm{CO}_{2}$ w przeliczeniu na jednostkę obszaru na rok, b) jako emisję GHG w kg ekwiwalentu $\mathrm{CO}_{2} \mathrm{w}$ przeliczeniu na $\mathrm{kg}$ produktu. Analizę śladu węglowego prowadzono według metodyki LCA (pol. Ocena Cyklu Życia), tj. od wydobycia surowców przez produkcję główną aż do wykorzystania odpadów (Milà i Canals i in., 2011). Metodyka badań LCA 
obejmuje realizację czterech faz: określenie celu i zakresu, analizę zbioru wejść i wyjść, ocenę wpływu cyklu życia i interpretację.

Dane dotyczące emisji GHG obejmowały jej 3 zakresy: a) emisje bezpośrednie $\left(\mathrm{CO}_{2}\right.$, $\mathrm{CH}_{4}, \mathrm{~N}_{2} \mathrm{O}$ ) wytwarzane $\mathrm{w}$ trakcie spalania paliw przez ciagniki i maszyny samobieżne biorące udział we wszystkich operacjach technologicznych uprawy rzepaku, b) emisje bezpośrednie i pośrednie $\mathrm{N}_{2} \mathrm{O}$ z pól z uprawą rzepaku w wyniku stosowania nawozów mineralnych, c) emisje pośrednie, wyrażone $\mathrm{w}$ ekwiwalencie $\mathrm{CO}_{2}$, związane $\mathrm{z}$ produkcja nawozów mineralnych, pestycydów, wykorzystaniem energii elektrycznej oraz ciagników i maszyn rolniczych. Emisje tego zakresu są właściwe dla etapu wstępnego cyklu życia rzepaku. Wiążą się one $\mathrm{z}$ łańcuchem dostaw środków produkcji do uprawy roślin i nie należą w sposób bezpośredni do modułu podstawowego, jakim jest polowa uprawa rzepaku.

Emisje bezpośrednie $\mathrm{i}$ pośrednie $\mathrm{N}_{2} \mathrm{O}$ związane ze stosowaniem nawozów mineralnych obliczono na podstawie metodologii IPCC (2006a) i EMEP/CORINAIR (2013). Do obliczeń emisji gazów cieplarnianych generowanych przy spalaniu paliwa przez ciagniki w trakcie prac polowych wykorzystano współczynniki emisji dla różnego rodzaju paliw i technologii przetwarzania energii (silników) podane w EMEP/CORINAIR (2013). Wielkość emisji przypisaną etapowi produkcji nawozów mineralnych i dystrybucji obliczono na podstawie ilości stosowanych nawozów oraz współczynników emisji. Według źródeł literaturowych wynosiły one odpowiednio: $2,792 \mathrm{~kg} \mathrm{CO}_{2} \mathrm{ekw} \cdot \mathrm{kg}^{-1} \mathrm{~N}, 0,738 \mathrm{~kg} \mathrm{CO}_{2}$ ekw. $\mathrm{kg}^{-1} \mathrm{P}_{2} \mathrm{O}_{5}$ i $0,352 \mathrm{~kg} \mathrm{CO}_{2}$ ekw. $\mathrm{kg}^{-1} \mathrm{~K}_{2} \mathrm{O}$ (GHGenius, 2010). Dwukrokową procedure obliczeń zastosowano do kalkulacji emisji GHG w produkcji, pakowaniu i dystrybucji pestycydów. W pierwszym kroku herbicydy, fungicydy oraz insektycydy przeliczono na jednostki energetyczne w MJ według wskaźników jednostkowej energochłonności skumulowanej ${ }^{2}$ w MJ $\mathrm{kg}^{-1}$ s.a. W następnym kroku określono wielkość emisji GHG przyjmując współczynnik emisji, związany ze zużyciem energii w procesie produkcji pestycydów, równy $0,069 \mathrm{~kg} \mathrm{CO}_{2}$ ekw. $\mathrm{MJ}^{-1}$ (Audsley i in., 2009). W analogiczny sposób obliczono emisję pośrednią GHG powstałą łącznie w procesie produkcji surowców, półproduktów i produkcji finalnej ciagników i maszyn rolniczych. W pierwszej kolejności, dla każdego ciągnika i maszyny rolniczej określono wielkość energii skumulowanej ${ }^{3}$, jaka została przekazana w MJ w ciagu jednej godziny ich użytkowania (na podstawie wskaźników jednostkowej energochłonności skumulowanej w $\mathrm{MJ} \mathrm{\textrm {kg } ^ { - 1 }}$, wg Harasima (2002), masy sprzętu, części zamiennych i materiałów do napraw w kg oraz czasu pracy w całym okresie eksploatacji w h). Następnie, zużycie energii skumulowanej (w $\mathrm{MJ} \mathrm{h}^{-1}$ ) zaangażowanych ciaggników i maszyn przeliczono na 1 ha powierzchni uprawy rzepaku wykorzystując dane o czasie użytkowania sprzętu w produkcji rzepaku ozimego i powierzchni uprawy. Masę zużytych części zamiennych określono na poziomie $30 \%$ masy ciaggnika. Materiały do napraw stanowiły 4\% masy części zamiennych (Harasim, 2002). Pośrednią emisję GHG związaną $\mathrm{z}$ ponoszeniem nakładów energii skumulowanej ciaggników i maszyn rolniczych na produkcję rzepaku ozimego obliczono w oparciu o MJ zużytej energii skumulowanej oraz ogólnie stosowane wartości współczynników emisji

\footnotetext{
${ }^{2}$ Jednostkowa energochłonność skumulowana - sumaryczny nakład energii zawarty w jednostce masy, włożony na wytworzenie produktu w całym ciągu wszystkich procesów związanych bezpośrednio i pośrednio z jego wytwarzaniem

${ }^{3}$ Energia skumulowana - sumaryczne, skumulowane zużycie energii w całym łańcuchu ogniw i procesów od pozyskania surowców pierwotnych, wytwarzania materiałów aż do wytworzenia produktu finalnego.
} 
GHG w sektorze przemysłowym dla poziomu węzła $1^{4}$ obliczeń emisji, nieuwzględniającego zróżnicowań krajowych emisji (IPCC, 2006b).

\section{Wyniki i dyskusja}

Obliczone średnie wartości CF rzepaku ozimego, w odniesieniu do $1 \mathrm{t}$ nasion oraz 1 ha powierzchni uprawy (przy średnim plonie 3,07 $\mathrm{t} \mathrm{ha}^{-1}$ ) wynosiły odpowiednio 794,3 $\mathrm{kg} \mathrm{CO}_{2}$ ekw. oraz 2441,7 kg CO 2 ekw. (rys. 1A, B). W pracy Borzęckiej-Walker i in. (2011) dotyczącej przedstawienia efektów środowiskowych w uprawie roślin energetycznych w Polsce podano wysoką wartość emisji GHG dla rzepaku ozimego wynoszącą około 4,5 t $\mathrm{CO}_{2}$ ekw. ha ${ }^{-1}$. Dokładna analiza metod i materiałów przedstawiona w publikacji przez tych autorów wskazuje, że przyczyną różnic jest niekomplementarność zastosowanych metod do oceny emisji GHG.

W badaniach własnych zastosowano pełną metodę LCA, natomiast $\mathrm{w}$ badaniach Borzęckiej-Walker - uproszczoną metodę LCA, wykorzystującą opublikowany w literaturze wskaźnik potencjału ocieplającego, w $\mathrm{kg}$ równoważnika $\mathrm{CO} 2 \mathrm{na} 1 \mathrm{t}$ plonu. W oparciu o ten wskaźnik oraz średni, statystyczny plon w kraju szacowano wielkość emisji GHG w odniesieniu do 1 ha. W warunkach Danii emisje GHG związane z uprawą rzepaku, przy uwzględnieniu różnic regionalnych, wahały się w wąskim zakresie od 2,3 do 2,4 tha1. Spośród wyróżnionych operacji technologicznych w uprawie rzepaku nawożenie mineralne miało największy wpływ na impakt potencjału globalnego ocieplenia. W wartościach bezwzględnych nawożenie generowało emisję 623,5 kg CO2 ekw. na $1 \mathrm{t}$ nasion, co odpowiadało emisji 1922,9 kg CO2 ekw. w odniesieniu do 1 ha powierzchni. Dominujące znaczenie w strukturze udziału operacji technologicznych w CF miało nawożenie mineralne (rys. 2). Względny udział tego nawożenia w CF przekraczał średnio $78 \%$. W wynikach Iriarte i in. (2010) impakt nawożenia był jeszcze wyższy i przekraczał $80 \%$. Uprawa i siew były drugim w kolejności komponentem CF, jednak na wielokrotnie niższym poziomie - około 9\%. Pozostałe operacje technologiczne wywierały jeszcze mniejszy wpływ na ślad węglowy. Ich udział wahał się w zakresie od $6,1 \%$ do $6,3 \%$. Wyniki badań wskazują, że główne znaczenie w całym cyklu nawożenia mineralnego w produkcji rzepaku miały emisje bezpośrednie i pośrednie GHG z pól (rys. 3). Średnia emisja GHG z pól, związana ze stosowaniem nawozów mineralnych, wynosiła około 391 kg CO2 ekw. t-1 nasion, co stanowiło około $63 \%$ emisji GHG w procesie nawożenia.

\footnotetext{
${ }^{4}$ Poziom węzła 1 oznacza referencyjne, domyślne wartości współczynników emisji GHG według raportu IPCC, bez odniesienia się do różnic krajowych i technologicznych.
} 

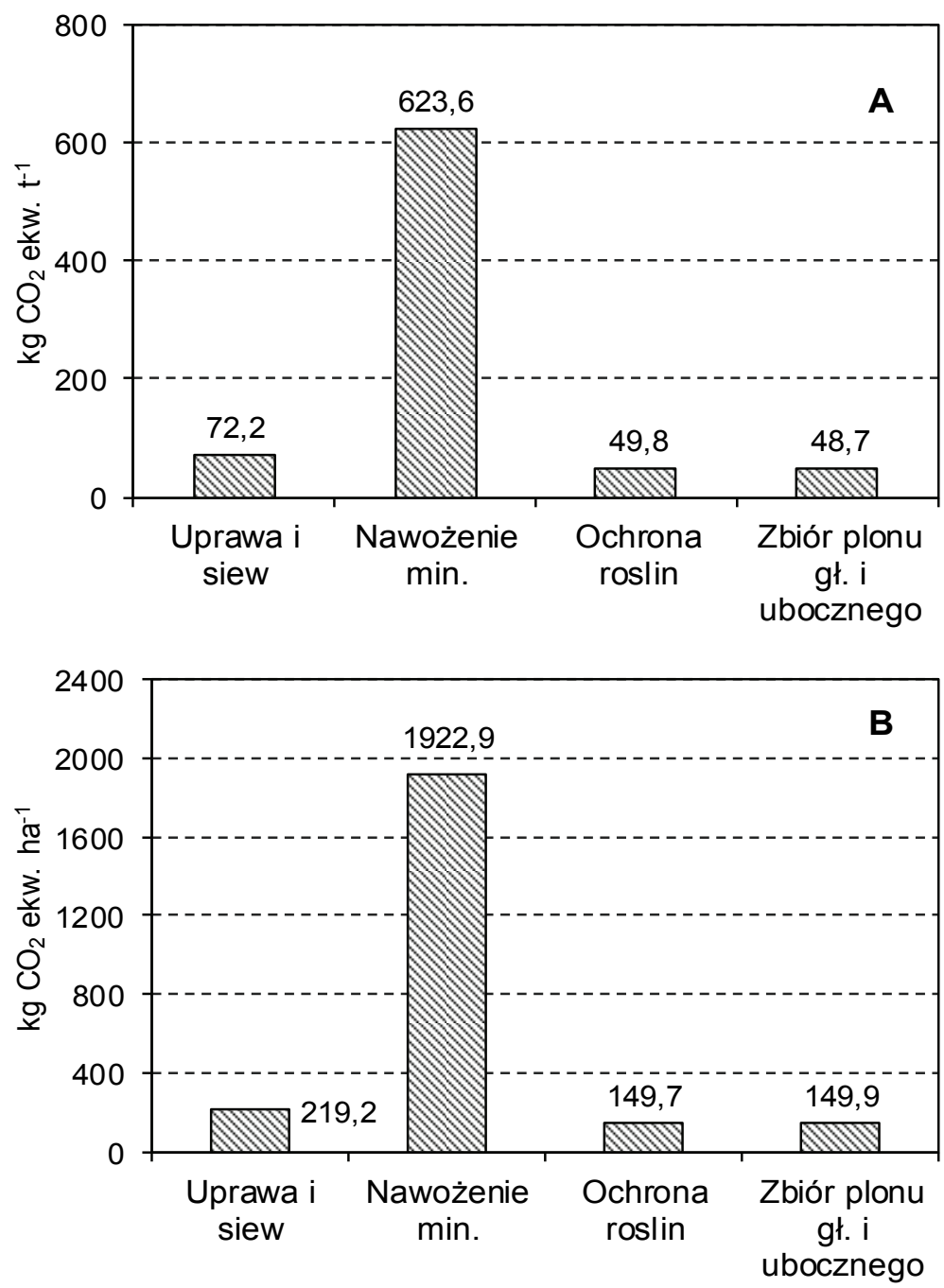

Rys. 1. Ślad węglowy rzepaku ozimego według operacji technologicznych w przeliczeniu na $1 \mathrm{t}$ nasion rzepaku (A) oraz na jednostkę powierzchni (B) w analizowanym przedsiębiorstwie (średnie z lat 2011-2014).

Fig. 1. Carbon footprint of winter rape according to the technological operations per $1 \mathrm{t}$ grain (A) and per area unit (B) for the analyzed corporate farming enterprise

Źródło: obliczenia własne. 


\section{J. Bieńkowski, M. Holka, J. Jankowiak}

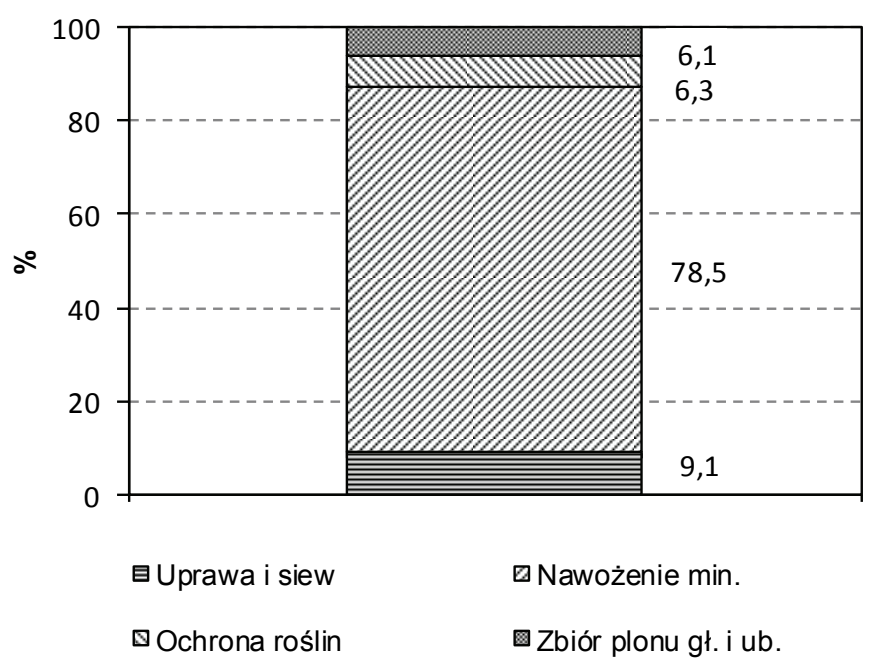

Rys. 2. Struktura udziału operacji technologicznych w śladzie węglowym rzepaku ozimego. Ślad węglowy ogółem równa się $100 \%$

Fig. 2. Share structure of technological operations in carbon footprint of winter rape. Total carbon footprint equals to $100 \%$

Źródło: obliczenia własne.

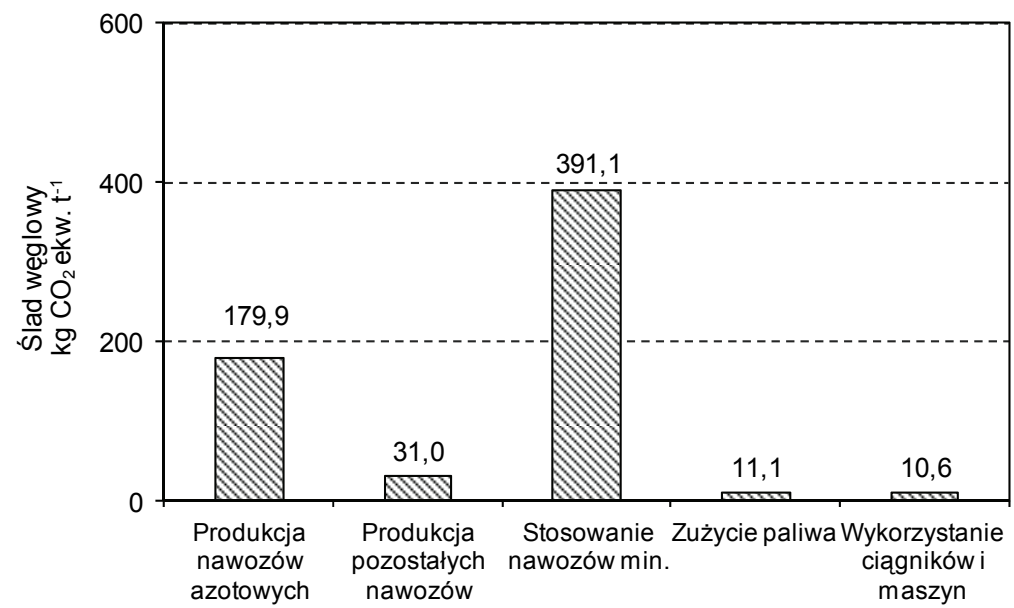

Rys. 3. Ślad węglowy związany z procesem nawożenia mineralnego rzepaku w badanym przedsiębiorstwie. Fig. 3. Carbon footprint associated with the mineral fertilization process for the analyzed farming enterprise Źródło: obliczenia własne. 
Badania Queirós i in. (2015) wykazują, że wybór typu nawozu ma istotne znaczenie dla oceny skutków środowiskowych produkcji rzepaku. Wysokie emisje GHG wiażą się przede wszystkim ze stosowaniem w nawożeniu mineralnym saletry wapniowo-amonowej. Według tych autorów wynikają one $\mathrm{z}$ dużego ładunku emisji GHG towarzyszącego produkcji tego nawozu na etapie przemysłowym. W konwencjonalnym systemie uprawy rzepaku w Polsce potencjalnie duże zagrożenie wysoką emisją GHG równą $896 \mathrm{~kg} \mathrm{CO}_{2}$ ekw. $\mathrm{t}^{-1}$ nasion istniałoby $\mathrm{w}$ przypadku realizacji scenariusza nawożenia, $\mathrm{w}$ którym saletra wapniowo-amonowa i nawozy NPK posiadałyby odpowiednio $74 \%$ i $26 \%$ udziałów w dawce nawozów azotowych (Queirós i in., 2015). W ogólnym ładunku emisji z nawożenia mineralnego produkcja nawozów stanowiła 29\%. Blisko sześciokrotnie niższe emisje GHG występowały w produkcji nawozów fosforowych i potasowych w porównaniu do nawozów azotowych. Marginalne znaczenie miały emisje związane ze zużyciem paliwa oraz emisje wynikające $\mathrm{z}$ wykorzystania ciagnników i maszyn w pracach polowych w uprawach rzepaku i transporcie wewnętrznym. Łącznie odpowiadały one za mniej niż 4\% ogólnej emisji z nawożenia. Emisje z pól związane z nawożeniem w badanym przedsiębiorstwie były 2krotnie wyższe niż dla upraw rzepaku i gorczycy w warunkach kanadyjskich (Gan i in., 2012). Modyfikacja praktyk nawozowych poprzez ich agregowanie z siewem roślin może w przyszłości istotnie przyczyniać się do dalszego obniżania CF w produkcji rzepaku nie tylko w badanym przedsiębiorstwie, ale może mieć szerszy zasięg w regionie Wielkopolski i także w całym kraju. W warunkach doświadczeń polowych o zróżnicowanym nawożeniu okazało się, że wielkość CF jest funkcją dawki nawozów azotowych (Gan i in., 2012). W zakresie dawek nawożenia azotowego 180-200 kg CF w badaniach kanadyjskich wynosił około $1000 \mathrm{~kg} \mathrm{CO} 2$ ekw. $\mathrm{t}^{-1}$ nasion, natomiast $\mathrm{w}$ badanym przedsiębiorstwie przy podobnym poziomie nawożenia był on niższy o ponad $200 \mathrm{~kg} \mathrm{CO}_{2}$ ekw. $\mathrm{t}^{-1}$ nasion. Przyczyną różnic w strukturze emisji z nawozów była inna technologia ich stosowania. W Kanadzie stosowano nawóz azotowy w formie jednorazowej dawki jednocześnie $\mathrm{z}$ siewem roślin, natomiast $\mathrm{w}$ badanym przedsiębiorstwie były to dawki wielokrotne i niełączone $\mathrm{z}$ zabiegiem siewu. Intensywność emisji GHG towarzysząca produkcji rzepaku należy uznać za stosunkowo umiarkowaną pomimo stosowania płużnego systemu uprawowego i dość wysokich dawek nawożenia azotowego.

Wielkości śladu węglowego rzepaku ozimego w badanym przedsiębiorstwie są porównywalne $\mathrm{z}$ wynikami niemieckimi uzyskanymi $\mathrm{w}$ badaniach bioenergetycznych systemów uprawowych w zachodnich Niemczech, w rejonie Trewiru. Ślad węglowy związany z uprawą rzepaku ozimego na tamtym obszarze wynosił $740 \mathrm{~kg} \mathrm{CO}$ ekw. $\mathrm{t}^{-1}$ nasion (Felten i in., 2013). W Finlandii w przeciętnych warunkach produkcyjnych, określonych na podstawie krajowej bazy rolniczej, ślad węglowy dla rzepaku wynosił 1480 $\mathrm{kg} \mathrm{CO} \mathrm{CO}_{2}$ ekw. $\mathrm{t}^{-1}$ nasion (Saarinen i in., 2012). Prawdopodobnie niska produktywność roślin wynikająca z trudnych warunków klimatycznych oraz z przeciętnie mniej żyznych gleb w Finlandii jest trwałą barierą ograniczająca produkcję, która nie może być łatwo usunięta przez postęp technologiczny. Z kolei rośliny oleiste (rzepak i gorczyca) uprawiane w Saskatchewan (Kanada), generowały ślad węglowy średnio w wysokości około $734 \mathrm{~kg} \mathrm{CO}$ ekw. $\mathrm{t}^{-1}$ nasion (Gan $\mathrm{i}$ in., 2012). Niższą emisję gazów GHG autorzy thumaczyli stosowaniem upraw bezorkowych i niższym nawożeniem azotowym.

Stosowanie zmianowania w uprawie roślin ma wpływ na redukcję śladu węglowego produktów roślinnych. W badaniach polowych ze zbożami udowodniono, że zróżnicowanie roślin uprawnych w zmianowaniu, w porównaniu do systemu monokulturowego, istotnie zmniejszało zużycie środków produkcji oraz zwiększało plon ziarna i słomy. Dzięki 
zmianowaniu uprawy rzepaku i zbóż charakteryzują się znacznie mniejszym CF. W zależności od przedplonu, np. w uprawie po roślinach oleistych i roślinach strączkowych, ślad węglowy pszenicy może być niższy od $7 \%$ do nawet $34 \%$, w porównaniu do sytuacji, gdy jej przedplonem jest inna roślina zbożowa (Gan i in., 2011). Liczne badania wykazały, że stosując ulepszone praktyki rolnicze takie jak: wczesny termin siewu, optymalną gęstość siewu oraz prawidłowe następstwo roślin w zmianowaniu można zwiększyć plony roślin, przy zachowaniu dotychczasowego poziomu nakładów produkcyjnych (Kirkegaard i in., 2008). Borzęcka-Walker i in. (2013) podkreślają znaczenie systemów uprawy uproszczonej i siewu bezpośredniego rzepaku ozimego dla redukcji emisji GHG. Według tych autorów, możliwe jest zmniejszenie emisji GHG o 54$59 \%$ przy dawce $180 \mathrm{~kg} \mathrm{~N} \mathrm{ha}^{-1}$, dzięki zwiększonemu potencjałowi retencjonowania $\mathrm{CO}_{2} \mathrm{w}$ glebach poprzez stosowanie uprawy bezorkowej. Wpływ praktyk rolniczych na wielkość CF jest także uzależniony od warunków glebowych.

W technologiach uprawy roslin poszukuje się możliwości zmniejszenia emisji GHG. Szacuje się, że roczna emisja GHG w produkcji roślinnej w Polsce wynosi ponad $13 \mathrm{mln} t$ (Poland's..., 2016). Sposobem ograniczenia emisji GHG związanej $\mathrm{z}$ produkcją i stosowaniem mineralnych nawozów azotowych jest wykorzystanie naturalnych procesów wiązania $\mathrm{N}$ przez uprawę roślin wiążących $\mathrm{N} \mathrm{z}$ atmosfery. Rośliny strączkowe żyjące w symbiozie $\mathrm{z}$ bakteriami brodawkowymi mogą korzystać $\mathrm{z} N$ cząsteczkowego i przekształcać go do $\mathrm{NH}_{3}$, nie powodując emisji $\mathrm{CO}_{2}$ do atmosfery. Znaczna część zasymilowanego przez symbiotyczne bakterie $\mathrm{N}$ zasila glebę w postaci resztek pożniwnych i masy korzeniowej. W przypadku roślin strączkowych ilość $\mathrm{N}$ pozostająca w glebie po ich zbiorach wynosi od 40 do 50\% (Herridge i in., 2008). Występowanie roślin strączkowych w systemach uprawowych obniża zatem zużycie mineralnych nawozów azotowych. Dodatkową korzyścią jest także wzrost produktywności roślin następczych w zmianowaniu.Dzięki temu zmniejsza się zależność rolnictwa od mineralnych nawozów azotowych oraz obniża się CF produktów roślinnych. Wpływ na zwiększenie efektywności wykorzystania $\mathrm{N}$ mają technologie nawożenia. W grupie czynników poprawnej technologii najważniejsza rolę odgrywają: pasowe nawożenie, odpowiedni termin aplikacji nawozów, podział dawek, dostosowanie poziomu nawożenia do zróżnicowania przestrzennego warunków glebowych i zasobności gleb w składniki pokarmowe (Peng i in., 2010).

Potencjalny wpływ na obniżenie emisyjności GHG w rolnictwie ma również przemysł nawozów sztucznych. Emisje GHG na etapie produkcji nawozów mineralnych są uzależnione od wydajności procesów syntezy związków azotowych, zapotrzebowania na gaz ziemny oraz energię cieplną i elektryczną w fabrykach nawozów. W literaturze podaje się, że w przeliczeniu na 1 tonę $\mathrm{N}$ emisje GHG wynoszą między 2,6 a 9,7 t $\mathrm{CO}_{2}$ ekw. (Snyder i in., 2009). Średni wskaźnik emisji GHG na 1 tonę nawozów produkowanych w Polsce wynosi 3,4 t $\mathrm{CO}_{2}$ ekw., przy znacznym zróżnicowaniu emisji w zależności od rodzaju nawozu azotowego w przedziale od 2,0 t dla siarczanu amonu do 5,3 $\mathrm{t} \mathrm{CO}_{2} \mathrm{ekw}$ dla Saletrosanu ${ }^{\circledR} 26$ makro (Borzęcka-Walker i in., 2013). Postęp technologiczny w przemyśle nawozowym prowadzi do systematycznego obniżania tych emisji. Konwersja $\mathrm{NH}_{3}$, będącego wyjściową formą $\mathrm{N}$ mineralnego w procesie Haber-Bosch'a, do innych związków chemicznych takich jak: azotan amonu, mocznik wymaga dodatkowych nakładów energii, które w efekcie końcowym zwiększają emisję GHG na etapie produkcji nawozów. 


\section{Konkluzje}

Analiza emisji GHG za pomocą CF zyskuje na znaczeniu w związku z włączeniem rolnictwa do programu redukcji emisji w UE. CF jest ważnym narzędziem oceny zmian ilościowych emisji dla poszukiwania działań mitygacyjnych w produkcji rolniczej.

W uprawie roślin występuje szereg praktyk rolniczych, które są źródłem potencjalnie dużych emisji GHG. Najczęściej charakteryzują się one dużym zużyciem paliw kopalnych i energii. Spośród analizowanych operacji technologicznych, największe znaczenie w kształtowaniu się CF ma proces nawożenia mineralnego. Wpływ pozostałych procesów na CF jest wielokrotnie mniejszy. Obecnie istnieje szereg możliwości redukcji emisji GHG poprzez podejmowanie działań w kierunku zwiększenia efektywności nawożenia. Do dostępnych rozwiązań w tym zakresie zalicza się: optymalizację nawożenia, odpowiednie terminy i sposoby stosowania nawozów oraz nowe formy nawozów. Dalsze korzyści w ograniczeniu CF mogą być uzyskane poprzez agregację zabiegów uprawowych i uproszczone systemy uprawowe. CF obliczono dla granicy systemu obejmującego fazy od „kołyski do bramy gospodarstwa”. Uzyskane dane z produkcji polowej są niezbędne dla rozszerzenia analiz CF o etap przetwórczy w przemyśle i dystrybucję zarówno w łańcuchu dostaw produktów spożywczych, jak i przemysłowych.

\section{Literatura}

Audsley, E., Stacey, K., Parsons, D.J., Williams, A.G. (2009). Estimation of the greenhouse gas emissions from agricultural pesticide manufacture and use. Cranfield University, Cranfield, Bedford UK.

Bieńkowski, J., Jankowiak, J., Dąbrowicz, R., Holka, M. (2016). Poziom i przestrzenne zróżnicowanie emisji gazów cieplarnianych z rolnictwa w Polsce. Zagadnienia Doradztwa Rolniczego 1(83), 50-61.

Borzęcka-Walker, M., Faber, A., Jarosz, Z., Syp, A., Pudełko, R. (2013). Greenhouse gas emission from rape seed cultivation for FAME production in Poland. Journal of Food, Agriculture \& Environment 11, 1064-1068.

Borzęcka-Walker, M., Faber, A., Pudełko, R., Kozyra, J., Syp, A., Borek, R. (2011). Life cycle assessment (LCA) of crops for energy production. Journal of Food, Agriculture \& Environment 9, 698-700.

Communication from the Commission to the Council and the European Parliament 2007. Renewable energy road map, renewable energies in the 21st century: building a more sustainable future. COM (2006) 848 final, Brussels.

Dyrektywa 2009/28/WE Parlamentu Europejskiego i Rady z dnia 23 kwietnia 2009 w sprawie promowania stosowania energii ze źródeł odnawialnych zmieniająca i w następstwie uchylająca dyrektywy 2001/77/WE oraz 003/30/WE. 2009: Official J. European Union L 140, 16-62.

Elsgaard, L., Olesen, J., Hermansen, J., Kristensen, I., Børgesen, C. (2013). Regional greenhouse gas emissions from cultivation of winter wheat and winter rapeseed for biofuels in Denmark. Acta Agriculturae Scandinavica, section B - Soil \& Plant Science 63, 219-230.

EMEP/EEA Air Pollutant Emission Inventory Guidebook (2013). Technical guidance to prepare national emission inventories. EEA Technical Report No 12/2013, European Environment Agency, Publications Office of the European Union, Luxembourg.

European Council Conclusions (2014). 2030 Climate and energy policy framework. EUCO 169/14. Pobrano grudzień 2015 z: www.consilium.europa.eu/uedocs/cms data/docs/pressdata/en/ec/ 145397.pdf.

FAO (2009). Global agriculture towards 2050. High Level Expert Forum - how to feed the world in 2050 Agricultural Development, Agricultural Development Economics Division, 12-13 October Rome.

Felten, D., Fröba, N., Fries, J., Emmerling, C. (2013). Energy balances and greenhouse gas-mitigation potentials of bioenergy cropping systems (Miscanthus, rapeseed, and maize) based on farming conditions in Western Germany. Renewable Energy 55, 160-174.

Gan, Y., Huang, G., Gan, Y., Liang, C., Malhi, S.S., Brandt, S.A., Katepa-Mupondwa, F. (2012). Carbon footprint of canola and mustard is a function of the rate of $\mathrm{N}$ fertilizer. Int. J. Life Cycle Assess. 17, 58-68.

Gan, Y., Liang, C., Wang, X., McConkey, B. (2011). Lowering carbon footprint of durum wheat by diversifying systems. Field Crops Research 122, 199-206. 
GHGenius (2010). GHGenius model 3.17. Natural Resources Canada, Ottawa.

Golub, A., Henderson, B., Hertel, T., Gerber, P., Rose, S., Sohngen, B. (2013). Global climate policy impacts on livestock, land use, livelihoods, and food security. PNAS 110, 20894-20899.

Harasim, A. (2002). Kompleksowa ocena płodozmianów z różnym udziałem roślin zbożowych i okopowych, Monografie i Rozprawy Naukowe 1, Wyd. IUNG Puławy.

Herridge, D., Peoples, M., Boddey, R. (2008). Global inputs of biological nitrogen fixation in agricultural systems. Plant Soil 311, $1-18$.

IPCC 2006a: 2006 IPCC Guidelines for National Greenhouse Gas Inventories. Volume 4 Agriculture, Forestry and Other Land Use. Pobrane z: http://www.ipcc-nggip. iges.or.jp /public/2006gl/vol4.htm.

IPCC 2006b: 2006 IPCC Guidelines for national greenhouse gas inventories. Volume 2 Energy. IGES Hayama, Japan.

Iriarte, A., Rieradevall, J., Gabarrell, X. (2010). Life cycle assessment of sunflower and rapeseed as energy crops under Chilean conditions. Journal of Cleaner Production 18, 336-345.

Kirkegaard, J., Christen, O., Krupinsky, J., Layzell, D. (2008). Break crop benefits in temperature wheat production. Field Crops Res. 54, 185-195.

Matthews, H.S.; Weber, C., Hendrickson, C. (2008). Estimating Carbon Footprints with Input-Output Models. International Input-Output Meeting on Managing the Environment, Seville, July 9-11, 1-10.

Milà i Canals, L., Sim, S., García-Suárez, T., Neuer, G., Herstein, K., Kerr, C. Rigarlsford, G., King, H. (2011). Estimating the greenhouse gas footprint of Knorr. Int. J. Life Cycle Assess. 16, 50-58.

Peng, S., Buresh, R., Huang, J., Zhong, X., Zou, Y., Yang, J., Wang, G., Liu, Y., Hu, R., Tang, Q., Cui, K., Zhang, F., Dobermann, A. (2010). Improving nitrogen fertilization in rice by site-specific N management- a Review, Agron. Sustain. Dev. 30, $649-656$.

Poland's National Inventory Report 2016 (2016). Greenhouse Gas Inventory for 1988-2014. IOŚ-PIB, KOBIZE, Warszawa.

Queirós, J., Malça, J., Freire, F. (2015). Environmental life-cycle assessment of rapeseed produced in Central Europe: addressing alternative fertilization and management practices. Journal of Cleaner Production 99, 266-274.

Saarinen, M., Virtanen, Y., Hyvärinen, H. (2012). LCAs for a large repertoire of Finnish outdoor plant products. Proceedings 8th International Conference on Life Cycle Assessment on the Agri-Food Sector, October 1-4 2012 Saint-Malo, France, 811-812.

Snyder, C., Bruulsema, T., Jensen, T., Fixen, P. (2009). Review of greenhouse gas emissions from crop production systems and fertilizer management effects. Agriculture, Ecosystems and Environment 133, 247-266.

Solomon, S., Qin, D., Manning, M., Chen, Z., Marquis, M., Averyt, K, Tignor, M., Miller, H. (2007). Climate change 2007- the physical science basis. Contribution of Working Group I to the Fourth Assessment Report of the Intergovernmental Panel on Climate Change, Cambridge University Press, Cambridge, United Kingdom and New York, NY, USA. 